\title{
Enrichment of Biscuits with Andaliman and Fermented Buffalo Milk Biscuits for the Intervention of Malnutrition in Children Under Five
}

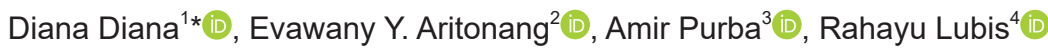 \\ ${ }^{1}$ Public Health Doctoral Program, Faculty of Public Health, Universitas Sumatera Utara, Medan, Indonesia; ${ }^{2}$ Department of \\ Community Nutrition, Faculty of Public Health, Universitas Sumatera Utara, Medan, Indonesia; ${ }^{3}$ Department of Communication, \\ Faculty of Social and Politics, Universitas Sumatera Utara, Medan, Indonesia; ${ }^{4}$ Department of Epidemiology, Faculty of Public \\ Health, Universitas Sumatera Utara, Medan, Indonesia
}

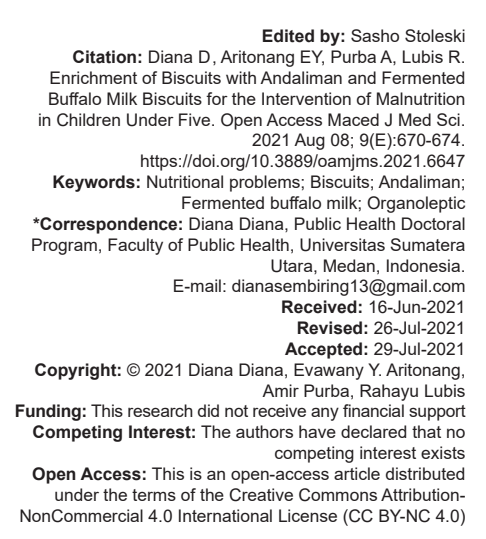

\begin{abstract}
BACKGROUND: Nutritional problems in children under 5 in Indonesia are very large and need effective intervention. Local ingredient is potential to create enrichment biscuits.

AIM: This study aims to produce biscuits enriched with Andaliman (Zanthoxylum acanthopodium) and fermented buffalo milk and to perform organoleptic tests on the taste, color, aroma, and texture of the biscuits.

METHODS: Three types of biscuits were made, namely, biscuits without Andaliman and fermented buffalo milk, biscuits with $2 \mathrm{~g}$ of Andaliman and $200 \mathrm{~g}$ of fermented buffalo milk, and biscuits with $3 \mathrm{~g}$ of Andaliman and $200 \mathrm{~g}$ of fermented buffalo milk. The all three biscuits were then tested organoleptically in the form of preferences by a panel of expert teachers to see choices for taste, color, aroma, and texture. The biscuits are then tested in a laboratory to assess their nutritional content.

RESULTS: Biscuits with $2 \mathrm{~g}$ of Andaliman and $200 \mathrm{~g}$ of fermented buffalo milk had the greatest preference. Statistically, the three groups of biscuits differed in taste, aroma, and texture $(p<0.05)$. The nutritional content of
\end{abstract} biscuits is above the standards set by the Ministry of Health.

CONCLUSION: Biscuits containing $2 \mathrm{~g}$ of Andaliman and $200 \mathrm{~g}$ of fermented buffalo milk have the potential to be produced as one of the intervention methods for under 5-year-old children malnutrition in Indonesia.

\section{Introduction}

Nutritional problems in children under 5 in Indonesia are very large compared to all countries in the Asian region. While stunting in Asia is in the $20 \mathrm{~s} \%$, stunting in Indonesia is in the $30 \mathrm{~s} \%$ [1]. Moreover, while the wasting level in Asia is around 9.1\%, in Indonesia, it is still at $10.2 \%$ [2]. More than half of Indonesia's 34 provinces have stunting rates higher than the national average, with the worst case accounting for $42.6 \%$ of the population. Meanwhile, 22 provinces had a wasting rate higher than the national average, with the worst condition at $14.4 \%$ [1]. Even the incidence of stunting in Indonesia is at the fifth largest position of all countries with the largest stunting burden in the world [3]. According to the UNICEF Indonesia, three out of every 10 children under the age of 5 in Indonesia are stunted and one is wasting [4].

The consequences of this nutritional deficiency are enormous not only in terms of the expense of recovery [5], [6] but also in terms of the long-term consequences. Those who have been malnourished since infant and young children will have physical issues that make them more susceptible to sickness, and their mental development and brain abilities are significantly lower than those who consume enough nutritional intake [7], [8]. Finally, this situation will have an impact on the capability and productivity of human resources (human capital) in families, communities, and possibly entire countries [9], [10]. Because the critical period for malnutrition is between the ages of 3 months and 2 years, malnutrition during this age must, therefore, be avoided as early as possible. At that age range, each child will begin to learn to eat and be given food, the pattern and content of which will greatly affect their growth in the future [11].

Thus, providing food intake that is in accordance with the demands of children under the age of 5 is one of the efforts that may be done to avoid the situation from worsening, or even to improve the condition of malnutrition. Children under the age of 5 who eat "dairy, vegetable, and fruit" had a higher height measurement than those who eat "grain based" or "egg, meat, poultry, and legumes" diets only [12]. Food treatments tailored to the nutritional needs of children under the age of 5 are also successful in improving their nutritional status [13], [14]. Even the intervention of regularly consuming nutritious foods since the mother's pregnancy has been proven to be helpful in 
lowering stunting in newborns for up to 1000 days when compared to the control group [15].

Enrichment biscuits with important nutrition will increase the effectiveness of food interventions to tackle malnutrition in children under the age of 5 . Biscuits are usually given by mothers to teach their children to eat. In addition, biscuits are also easy to make with available local ingredients. One of the local food ingredients that are commonly used by the community is Andaliman and fermented buffalo milk. Andaliman (Zanthoxylum acanthopodium) also known as "batak pepper" is a group of citrus fruits that contain Vitamins $\mathrm{C}$ and $\mathrm{E}$, making it beneficial to the immune system. Andaliman also contains essential oils and alkaloids that are useful for antioxidants and antimicrobials [16], [17], [18]. Fermented buffalo milk or in the local language called "dali ni horbo" has very good nutritional content [19]. Vitamin B12, riboflavin, Vitamin A, Vitamin C, Vitamin B6, thiamin, folic acid, amino acids, and niacin are all present in a cup of buffalo milk. Compared to other dairy products, buffalo milk is low in cholesterol so it can reduce lowdensity lipoprotein levels. The fat content of buffalo milk is also higher than that of cow's milk. One hundred grams of buffalo milk contain 100 calories and $275 \mathrm{mg}$ of total cholesterol, whereas $100 \mathrm{~g}$ of cow's milk contains only 70 calories and $212 \mathrm{mg}$ of cholesterol. As a result, it promotes weight gain and muscular mass [20].

The aim of this research is to use Andaliman and fermented buffalo milk as biscuit ingredients. Organoleptic assessment will be performed to determine the biscuits' preferences.

\section{Materials and Methods}

Biscuits are made using the basic ingredients for making cookies, that is, $100 \mathrm{~g}$ of sugar, two egg yolks, $300 \mathrm{~g}$ of flour, and $150 \mathrm{~g}$ of butter. The basic dough is then divided into two parts. The first dough is then added Andaliman which has been mashed as much as $3 \mathrm{~g}$ and fermented buffalo milk as much as $200 \mathrm{~g}$. The second dough is added with Andaliman which has been mashed as much as $2 \mathrm{~g}$ and fermented buffalo milk as much as $200 \mathrm{~g}$. Each dough is then formed into a circle weighing $13 \mathrm{~g}$. Then, the dough is put in the oven at $170^{\circ} \mathrm{C}$ for $25 \mathrm{~min}$. The weight of one piece of biscuit after the baking process is $10 \mathrm{~g}$.

Figure 1 shows the comparison of $A$ (biscuits without Andaliman and fermented milk), B (biscuits with $3 \mathrm{~g}$ of Andaliman and $200 \mathrm{~g}$ of fermented buffalo milk), and C (biscuits with $2 \mathrm{~g}$ of Andaliman and $200 \mathrm{~g}$ of fermented buffalo milk) biscuits.

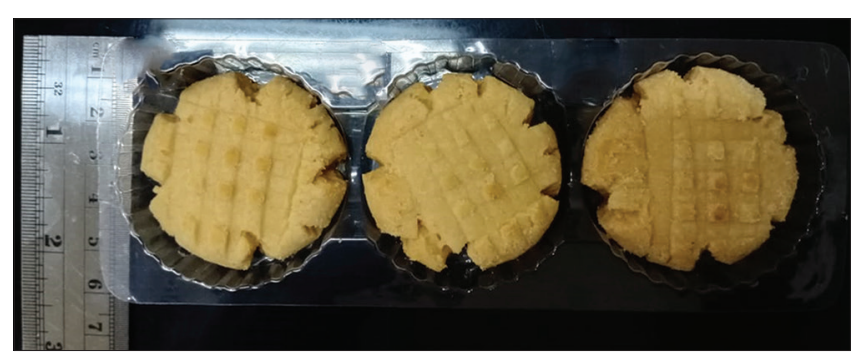

Figure 1: $A, B$, and $C$ biscuits final result comparison

\section{Organoleptic test}

Panelists comprised 20 instructors from SMK Negeri 8 Medan's evaluated the biscuits prepared. The aroma, color, taste, and texture of three types of biscuits, namely, biscuit without Andaliman and fermented milk (A biscuit), biscuit with $3 \mathrm{~g}$ of Andaliman and $200 \mathrm{~g}$ of fermented buffalo milk (B biscuit), and biscuit with $2 \mathrm{~g}$ of Andaliman and $200 \mathrm{~g}$ of fermented buffalo milk ( $C$ biscuit), were tested in organoleptic tests. The assessment of biscuits for each component used the indicators of "dislike very much," "dislike," "somewhat like," "like," and "like very much." Each indicator is rated on a scale of $1-5$. The results are then calculated and then divided by five to get the average rating for each component. The difference between the assessments according to each biscuit was carried out using the ANOVA test at a $95 \%$ confidence level.

\section{Composition test}

To determine the composition of biscuits, a nutritional analysis of biscuits was carried out at the Laboratory of the Industrial Research and Development Agency of the Central Agro Industry Center, Bogor, West Java.

\section{Location and ethical permit}

This research was conducted at SMK Negeri 8 Medan. This research has been approved by the Health Research Ethics Commission of the USU Faculty of Nursing No. 2006/II/SP/2020.

\section{Results}

Following the organoleptic test of all biscuits [Figure 1], A biscuits were rated "like" and "like very much" by $20 \%$ and $5 \%$ of respondents, respectively, in terms of taste, as shown in Table 1. B biscuits, on the other hand, received ratings of "like" and "like very much" from $55 \%$ and $35 \%$ of respondents, respectively. C biscuits are rated "like" by $55 \%$ of respondents and "like very much" by $10 \%$. According to the color 
Table 1: Organoleptic properties comparison of biscuits

\begin{tabular}{|c|c|c|c|c|c|c|c|c|c|c|c|c|c|}
\hline \multirow[t]{3}{*}{ Biscuits } & \multicolumn{12}{|c|}{ Degree of sensory } & \multirow[t]{3}{*}{ P-value } \\
\hline & \multicolumn{2}{|c|}{$\begin{array}{l}\text { Dislike very } \\
\text { much }\end{array}$} & \multicolumn{2}{|c|}{ Dislike } & \multicolumn{2}{|c|}{$\begin{array}{l}\text { Somewhat } \\
\text { like }\end{array}$} & \multicolumn{2}{|c|}{ Like } & \multicolumn{2}{|c|}{$\begin{array}{l}\text { Like very } \\
\text { much }\end{array}$} & \multicolumn{2}{|c|}{ Total } & \\
\hline & $\bar{f}$ & $\%$ & $\bar{f}$ & $\%$ & $\bar{f}$ & $\%$ & $\bar{f}$ & $\%$ & $\bar{f}$ & $\%$ & $\bar{f}$ & $\%$ & \\
\hline Taste & & & & & & & & & & & & & 0.000 \\
\hline A & 0 & 0 & 2 & 10 & 13 & 65 & 4 & 20 & 1 & 5 & 20 & 100 & \\
\hline B & 0 & 0 & 0 & 0 & 2 & 10 & 11 & 55 & 7 & 35 & 20 & 100 & \\
\hline C & 0 & 0 & 0 & 0 & 7 & 35 & 11 & 55 & 2 & 10 & 20 & 100 & \\
\hline Color & & & & & & & & & & & & & 0.019 \\
\hline A & 0 & 0 & 0 & 0 & 8 & 40 & 9 & 45 & 3 & 15 & 20 & 100 & \\
\hline B & 0 & 0 & 0 & 0 & 2 & 10 & 11 & 55 & 7 & 35 & 20 & 100 & \\
\hline C & 0 & 0 & 0 & 0 & 3 & 15 & 13 & 65 & 4 & 20 & 20 & 100 & \\
\hline Flavor & & & & & & & & & & & & & 0.000 \\
\hline A & 0 & 0 & 2 & 10 & 15 & 75 & 3 & 15 & 0 & 0 & 20 & 100 & \\
\hline B & 0 & 0 & 0 & 0 & 2 & 10 & 11 & 55 & 7 & 35 & 20 & 100 & \\
\hline C & 0 & 0 & 0 & 0 & 8 & 40 & 11 & 55 & 1 & 5 & 20 & 100 & \\
\hline Texture & & & & & & & & & & & & & 0.000 \\
\hline A & 6 & 30 & 9 & 45 & 5 & 25 & 0 & 0 & 0 & 0 & 20 & 100 & \\
\hline B & 0 & 0 & 0 & 0 & 3 & 15 & 11 & 55 & 6 & 30 & 20 & 100 & \\
\hline C & 0 & 0 & 1 & 5 & 7 & 35 & 11 & 55 & 1 & 5 & 20 & 100 & \\
\hline
\end{tabular}

A=Biscuits without Andaliman and fermented milk; B=Biscuits with $3 \mathrm{~g}$ of Andaliman

assessment, more informants rated $\mathrm{B}$ biscuits "like very much" $(35 \%)$, whereas only $15 \%$ and $20 \%$ rated $A$ and $\mathrm{B}$ biscuits "like very much," respectively. The aroma of $\mathrm{B}$ biscuits is also extremely remarkable. As many as $35 \%$ gave a "like very much" rating, while $\mathrm{C}$ biscuit was rated "like very much" by $5 \%$ of respondents. The aroma of $A$ biscuit did not receive a "like very much" grade from any of the responders. In the "like" rating, B and C biscuits received $55 \%$ each, but $A$ biscuits obtained only $15 \%$. $\mathrm{B}$ biscuits dominated the texture as well. About $30 \%$ gave it a "like very much" rating, while $55 \%$ gave it a "like" rating. While $5 \%$ of respondents said that they liked C biscuit's texture "like very much," and 55\% said that they liked it. The texture of A biscuits was rated "dislike" by the majority of respondents.

As can be seen, B biscuits strongly dominate the expert panel's preference [Figure 2]. The ANOVA test demonstrated that the difference in taste, aroma, and crunch between the three biscuits was statistically significant.

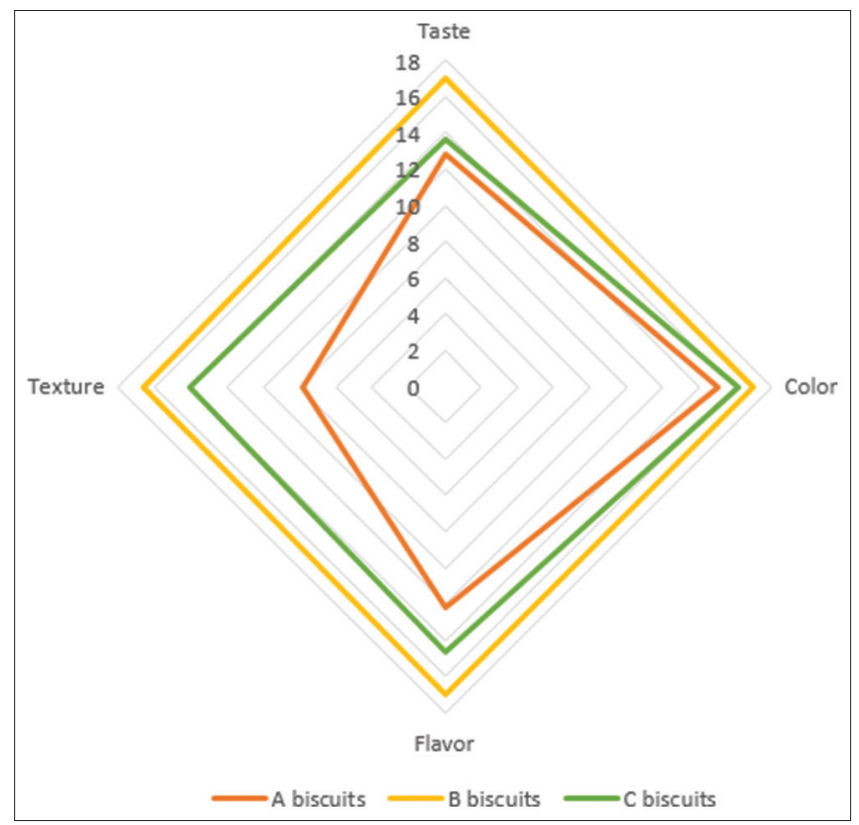

Figure 2: Expert panel preferences of biscuits
Following laboratory testing, the nutritional content of biscuits containing Andaliman ingredients and fermented buffalo milk, as well as biscuits without Andaliman and fermented buffalo milk, met the requirements of the Indonesian National Standard on biscuit quality. Aside from the organoleptic quality, $B$ biscuits contain significantly more protein, fat, and energy than A biscuit [Table 2].

Table 2: Nutritional composition of biscuits (B compare to $A$ )

\begin{tabular}{lllll}
\hline No. & Biscuit composition & B & A & SNI 01-2973-1992 \\
\hline 1. & Water (\%) & 4.50 & 1.93 & Max 5 \\
2. & Protein (\%) & 10.1 & 7.06 & $\operatorname{Min} 5$ \\
3. & Ash (\%) & 1.21 & 0.85 & $\operatorname{Max} 1.5$ \\
4. & Crude fiber (\%) & 0.38 & 0.42 & Max 0.5 \\
5. & Fat (\%) & 31.0 & 28.1 & Min 9.5 \\
6. & Carbohydrate (\%) & 52.8 & 61.3 & Min 7 \\
7. & Energy (kal/100 g) & 531 & 526 & Min 400 \\
\hline SNl: Indonesian National Standard & & &
\end{tabular}

\section{Discussion}

The Food Ingredients Composition List, which has been regulated by the government [21], [22], can be used to calculate the nutritional composition of biscuits. The nutritional composition of each biscuit must meet the following criteria: Energy of $59.1 \mathrm{kcal}$ and meet $3 \%$ of the recommended amount of energy per day; carbohydrates $7.2 \mathrm{~g}$ and meet $2 \%$ of the recommended amount per day; $1.2 \mathrm{~g}$ of protein and can meet $3 \%$ of the recommended amount per day; $3.0 \mathrm{~g}$ of fat and meet $4 \%$ of the recommended amount per day; Vitamin A meet $3 \%$ of the recommended amount per day; zinc meet $2 \%$ of the recommended amount per day; and iron meet $5 \%$ of the recommended amount per day.

Using this reference, it is reasonable to state that the biscuits in this research have a good nutritional composition and can fulfill the nutritional needs of children under the age of 5 . The results of the laboratory tests [Table 2] show that biscuits containing Andaliman and fermented milk have a very high nutritional value. According to it, biscuits containing Andaliman ingredients and fermented buffalo milk have a high protein, fat, and energy content as one of the functional food ingredients.

The biscuits product in this study [Figure 1] was found to be of much higher quality than the biscuits on the market. For the same size of a biscuit $(10 \mathrm{~g})$, one brand of biscuits sold and widely consumed in the community provides only $45 \mathrm{kcal}$ of energy, $1.5 \mathrm{~g}$ of fat, and $1 \mathrm{~g}$ of protein. It is clear that the biscuits on the market are very inadequate to function as functional food when compared to biscuits without Andaliman content and fermented buffalo milk alone, especially when compared to the enriched content ( $B$ and $C$ biscuits).

Malnutrition in children under the age of 5 , which has occurred in many countries, including Indonesia, 
is closely related to insufficient protein, fat, and energy consumption. This is a classic problem, the root cause of a malnutrition pandemic in developing countries [23]. The Indonesian Ministry of Health has established the recommended Dietary References Intake (DRI) in accordance with the WHO recommendation [24] regarding the composition of food required for children under the age of 5 . The required energy intake for children aged $1-3$ years is $1350 \mathrm{kcal}$, while the required energy intake for children aged 4-6 years is $1400 \mathrm{kcal}$. When there is a deficiency, it is classified as a deficit (70\% DRI or less) (70-80\% DRI). It means that the total energy requirement can be met with only three biscuits with Andaliman and fermented buffalo milk. Many studies have shown that interventions with micronutrients are effective in treating nutritional problems and preventing worsening conditions [25], [26], [27], [28].

Acceptance of the biscuits is related to sensory assessment [29]. Hence, to increase the acceptance of biscuits, organoleptic tests which are related to taste, color, aroma, and texture are very important. Biscuits made with Andaliman $2 \mathrm{~g}$ and fermented buffalo milk $200 \mathrm{mg}$ appear to have a taste that dominates the expert panel's preference [Figure 2], despite the fact that the expert panel prefers biscuits with less Andaliman (compared to $3 \mathrm{~g}$ of Andaliman). Production of these biscuits will undoubtedly be very quick and easy in the future not only because the ingredients for making these biscuits are plentiful in Indonesia but also because Andaliman and fermented buffalo milk have long been known and consumed by the general public. Local products have been shown to be more effective in efforts to improve nutritional problems [30], [31].

\section{Conclusion}

Biscuits containing $2 \mathrm{~g}$ of Andaliman and $200 \mathrm{~g}$ of fermented buffalo milk have the potential to be produced as a food intervention method to tackle malnutrition in under 5-year-old children in Indonesia.

\section{References}

1. Ministry of Health. Riskesdas (Basic Health Research) 2018. Jakarta: Ministry of Health; 2018.

2. Global Nutrition Report. Country Nutrition Profiles; 2021. Available from: https://www.globalnutritionreport.org/resources/ nutrition-profiles/asia/south-eastern-asia/indonesia. [Last accessed on 2021 May 19].

3. Titaley CR, Ariawan I, Hapsari D, Muasyaroh A, Dibley MJ. Determinants of the stunting of children in Indonesia: A multilevel analysis of the 2013 Indonesia basic health survey. Nutrients. 2019;11(5):1160. https://doi.org/10.3390/nu11051106

\section{PMid:31109058}

4. UNICEF Indonesia. Nutrition: Tackling the "Double Burden" of Malnutrition in Indonesia; 2021. Availale from: https://www. unicef.org/indonesia/nutrition. [Last accessed on 2021 May 19].

5. Nugent R, Levin C, Hale J, Hutchinson B. Economic effects of the double burden of malnutrition. Lancet. 2020;395(10218):156164. https://doi.org/10.1016/s0140-6736(19)32473-0

PMid:31852601

6. Suri DJ, Moorthy D, Rosenberg $\mathrm{IH}$. The role of dairy in effectiveness and cost of treatment of children with moderate acute malnutrition: A narrative review. Food Nutr Bull. 2016;37(2):176-85. https://doi.org/10.1177/0379572116633327 PMid:26936209

7. Moniaga JV, Ohyver M, Siregar J, Yauwito PH. Map-type modelling and analysis of children stunting case data in Indonesia with interactive multimedia method. Proc Comput Sci. 2019;157:530-6. https://doi.org/10.1016/j.procs.2019.09.010

8. Santos C, Bustamante A, Vasconcelos O, Pereira S, Garganta R, Tani G, et al. Stunting and physical fitness. The peruvian health and optimist growth study. Int J Environ Res Public Health. 2020;17(10):3440. https://doi.org/10.3390/ijerph17103440 PMid:32429040

9. Undurraga EA, Behrman JR, Emmett SD, Kidd C, Leonard WR, Piantadosi ST, et al. Child stunting is associated with weaker human capital among native Amazonians. Am J Hum Biol. 2018;30(1):1-18. https://doi.org/10.1002/ajhb.23059 PMid:28901592

10. Black MM, Pérez-Escamilla R, Rao SF. Integrating nutrition and child development interventions: Scientific basis, evidence of impact, and implementation considerations. Adv Nutr. 2015;6(6):852-9. https://doi.org/10.3945/an.115.010348 PMid:26875208

11. Wild CP, Miller JD, Groopman D, editors. Mycotoxin Contro di Low-and middle Income Countries, IARC Working Group Reports, No. 9. Lyon, FR: International Agency for Research on Cancer; 2015.

12. Melaku YA, Gill TK, Taylor AW, Adams R, Shi Z, Worku A Associations of childhood, maternal and household dietary patterns with childhood stunting in Ethiopia: Proposing an alternative and plausible dietary analysis method to dietary diversity scores. Nutr J. 2018;17(1):1-15. https://doi.org/10.1186/ s12937-018-0316-3

PMid:29378583

13. Lazzerini M, Rubert L, Pani P. Specially formulated foods for treating children with moderate acute malnutrition in low- and middle-income countries. Cochrane Database Syst Rev. 2013;6:CD009584. https://doi.org/10.1002/14651858. cd009584.pub2

PMid:23794237

14. Bhutta ZA, Akseer N, Keats EC, Vaivada T, Baker S, Horton SE, et al. How countries can reduce child stunting at scale : Lessons from exemplar countries. Am J Clin Nutr 2020;112:894-904. https://doi.org/10.1093/ajcn/nqaa153

15. Olney DK, Leroy J, Bliznashka L, Ruel MT. PROCOMIDA, a food-assisted maternal and child health and nutrition program, reduces child stunting in Guatemala: A cluster-randomized controlled intervention trial. J Nutr. 2018;148(9):1493-505. https://doi.org/10.1093/jn/nxy138 PMid:30184223

16. Kristanty RE, Suriawati J. The Indonesian Zanthoxylum acanthopodium DC.: Chemical and biological values. Int $\mathrm{J}$ PharmTech Res. 2015;8(6):313-21.

17. Julistiono $H$, Lestari $F G$, Iryanto $R$, Lotulung $P D$. Antimycobacterial activity of fruit of Zanthoxylum acanthopodium DC against Mycobacterium smegmatis. Avicenna J Phytomed. 
2018;8(5):432-8.

PMid:30345230

18. Hasibuan AZ, Haro G, Satria D. Evaluation of cytotoxic activity alkaloid Zanthoxylum acanthopodium DC. fruits. Open Access Maced J Med Sci. 2019;7(22):3745-7. https://doi.org/10.3889/ oamjms.2019.495

PMid:32127967

19. Grenov B, Michaelsen KF. Growth components of cow's milk: Emphasis on effects in undernourished children. Food Nutr Bull. 2018;39(2S):45-53. https://doi.org/10.1177/0379572118772766 PMid:29724127

20. Winarno FG, Fernandez IE. Susu dan Produk Fermentasinya. Bogor: M-Brio Press; 2007.

21. Ministry of Health. Pedoman Metode Melengkapi Nilai Gizi Bahan Makanan Pada Tabel Komposisi Pangan Indonesia. Jakarta: Ministry of Health; 2017.

22. Ministry of Health. Indonesian Food Composition Data, 2009. Jakarta: Ministry of Health; 2018. Available from: https://www. panganku.org/en-EN/beranda. [Last accessed on 2021 May 20].

23. Müller $\mathrm{O}$, Krawinkel M. Malnutrition and health in developing countries. CMAJ. 2005;173(3):279-86.

PMid: 16076825

24. World Health Organization. Technical Note: Supplementary Foods for the Management of Moderate Acute Malnutrition in Infants and Children 6-59 Months of Age. Geneva: World Health Organization; 2012.

25. de Pee S, Bloem MW. Current and potential role of specially formulated foods and food supplements for preventing malnutrition among 6- to 23-month-old children and for treating moderate malnutrition among 6- to 59-month-old children. Food Nutr Bull. 2009;30(3):434-63. https://doi. org/10.1177/15648265090303s305 PMid:19998866

26. Bhutta ZA, Das JK, Rizvi A, Gaffey MF, Walker N, Horton S, et al. Maternal and child nutrition 2 evidence-based interventions for improvement of maternal and child nutrition: What can be done and at what cost? Lancet. 2013;382(9890):452-77. https://doi. org/10.1016/s0140-6736(13)60996-4

PMid:23746776

27. Bhutta ZA, Ahmed T, Black RE, Cousens S, Dewey K, Giugliani $\mathrm{E}$, et al. What works? Interventions for maternal and child undernutrition and survival. Lancet. 2008;371(9610):41740. https://doi.org/10.1016/s0140-6736(07)61693-6 PMid:18206226

28. Scherbaum V, Purwestri RC, Stuetz W, Inayati DA, Suryantan J, Bloem MA, et al. Locally produced cereal/nut/legume-based biscuits versus peanut/milk-based spread for treatment of moderately to mildly wasted children in daily programmes on Nias Island, Indonesia: An issue of acceptance and compliance ? Asia Pac J Clin Nutr. 2015;24(1):152-61. https:// doi.org/10.5402/2013/412145

PMid:25740754

29. Erasmus EE, Tang EN, Achu MB, Boulanger R, Mbacham WF, Ndindeng SA. Physical, nutritional, and sensory quality of rice-based biscuits fortified with safou (Dacryodes edulis) fruit powder. Food Sci Nutr. 2020;8(7):3413-24. https://doi. org/10.1002/fsn3.1622

PMid:32724605

30. Lenters LM, Wazny K, Webb P, Ahmed T, Bhutta ZA. Treatment of severe and moderate acute malnutrition in low- and middleincome settings: A systematic review, meta-analysis and Delphi process. BMC Public Health. 2013;13(Suppl 3):S23. https://doi. org/10.1186/1471-2458-13-s3-s23 PMid:24564235

31. Sigh S, Roos N, Sok D, Dijkhuizen MA, Wieringa FT. Development and acceptability of locally made fish-based, ready-to-use products for the prevention and treatment of malnutrition in Cambodia. Food Nutr Bull. 2018;39(3):420-34. https://doi.org/10.1177/0379572118788266

PMid:30092653 